\title{
The Terrorist Attacks and the Human Live Birth Sex Ratio: a Systematic Review and Meta-Analysis
}

\author{
Gwinyai Masukume ${ }^{1,2}$, Sinéad M. O’Neill ${ }^{1}$, Ali S. Khashan ${ }^{1,3}$, Louise C. Kenny ${ }^{1}$, Victor Grech ${ }^{4, *}$
}

\section{ABSTRACT}

Aim: The live birth sex ratio is defined as male/total births (M/F). Terrorist attacks have been associated with a transient decline in $M / F$ 3-5 months later with an excess of male losses in ongoing pregnancies. The early 21st century is replete with religious/politically instigated attacks. This study estimated the pooled effect size between exposure to attacks and M/F. Registration number CRD42016041220. Methods: PubMed and Scopus were searched for ecological studies that evaluated the relationship between terrorist attacks from $1 / 1 / 2000$ to 16/6/2016 and M/F. An overall pooled odds ratio (OR) for the main outcome was generated using the generic inverse variance method. Results: Five studies were included: 2011 Norway attacks; 2012 Sandy Hook Elementary School shooting; 2001 September 11 attacks; 2004 Madrid and 2005 London bombings. OR at $0.9795 \% \mathrm{Cl}(0.94-1.00)\left(1^{2}=63 \%\right)$ showed a small statistically significant 3\% decline in the odds $(\mathrm{p}=0.03)$ of having a male live birth 3-5 months later. For lone wolf attacks there was a $10 \%$ reduction, OR $0.9095 \%$ $\mathrm{Cl}(0.86-0.95)(\mathrm{p}=0.0001)$. Conclusion: Terrorist (especially lone wolf) attacks were significantly associated with reduced odds of having a live male birth. Pregnancy loss remains an important Public Health challenge. Systematic reviews and meta-analyses considering other calamities are warranted.

\section{KEYWORDS}

population stress; sex ratio; pregnancy; stillbirth; miscarriage

AUTHOR AFFILIATIONS

${ }^{1}$ Irish Centre for Fetal and Neonatal Translational Research (INFANT), Department of Obstetrics and Gynaecology, University College Cork, Cork, Ireland

${ }^{2}$ Gravida: National Centre for Growth \& Development, University of Auckland, Auckland, New Zealand

${ }^{3}$ Department of Epidemiology and Public Health, University College Cork, Cork, Ireland

${ }^{4}$ Academic Department of Paediatrics, Medical School, Mater Dei Hospital, Malta

* Corresponding author: Academic Department of Paediatrics, Medical School, Mater Dei Hospital, Malta; e-mail: victor.e.grech@gov.mt

Received: 11 January 2017

Accepted: 3 April 2017

Published online: 5 October 2017

Acta Medica (Hradec Králové) 2017; 60(2): 59-65

https://doi.org/10.14712/18059694.2017.94

(C) 2017 The Authors. This is an open-access article distributed under the terms of the Creative Commons Attribution License (http://creativecommons.org/licenses/by/4.0), which permits unrestricted use, distribution, and reproduction in any medium, provided the original author and source are credited. 


\section{KEY NOTES}

- Male births occur slightly in excess of female but transiently dip following violent events, a potential Public Health issue.

- This study carried out a systematic review and meta-analysis of five recent terrorist events.

- Overall pooled odds ratio (OR) showed a $3 \%$ decline in the odds $(p=0.03)$ of having a male live birth 3-5 months after such events. For lone wolf attacks this was $10 \%$, OR $0.9095 \%$ CI $(0.86-0.95)$ ( $p=0.0001)$.

\section{AIM}

For centuries, the relative proportions of male and female births have fascinated and intrigued researchers (1). The human live birth sex ratio, also known as the secondary sex ratio, is defined as male live births $\div$ total births. This ratio is quick, easy and cheap to measure and it has been suggested since at least the 1990s that this ratio can be used as a sentinel health indicator in both industrialized and non-industrialized countries to monitor the health of populations (2).

Momentous events of our time exert varying degrees of stress on differing populaces, effects which may last from days to weeks. Such events include the September 11, 2001 (9/11) terrorist attacks (3), and Great East Japan Earthquake of 2011 (4) (which led to the Fukushima nuclear power plant disaster), all of which have been linked to significant declines in the sex ratio at birth in exposed populations. The contention that exogenous stress influences the human live birth sex ratio is underpinned by a large body of evidence from animal models, human epidemiologic studies and evolutionary theory (3). However, because the sex ratio at birth is an easy outcome to measure, multiple studies in this domain are performed with a high risk of publication bias from false positives (5).

While what would be deemed as terrorist attacks have occurred for centuries, we sought specifically to consider a contemporary period in the new millennium and century so that our results would be generalizable

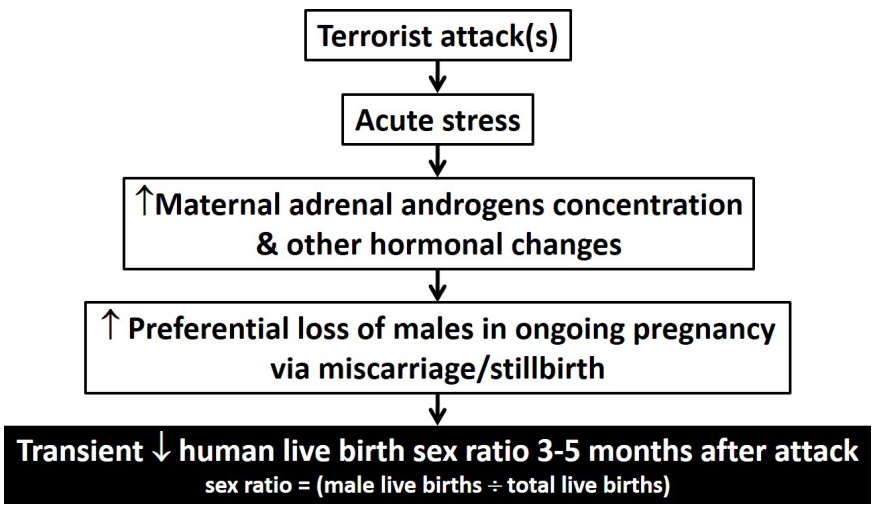

Fig. 1: Conceptual framework of the chain of events from a terrorist attack(s) leading to the excess in utero loss of males $(3,16)$. Transient/acute psychological stress acts via the adrenal glands causing perturbations in hormonal concentrations of androgens, cortisol, catecholamines and downstream reproductive hormones. to our time. Soon after the turn of the 21st century, the 9/11 terrorist attacks on the United States of America led to unprecedented global media attention and responses from governments (6). These attacks are spreading and increasing (7). A particular chain of events by which terrorist attacks culminate in an excess loss of unborn males via miscarriage or stillbirth leading to a reduced sex ratio at birth via maternal stress has been posited (Figure 1). Pregnancy loss remains an important public health challenge (3). Given the prominence of terrorist attacks, the aim of this systematic review was to investigate the effect of terrorist attacks on the human live birth sex ratio in the published literature to date and to provide a quantitative estimate of the magnitude of the effect in the form of a meta-analysis.

\section{METHODS}

The protocol for this systematic review and meta-analysis was registered on the International prospective register of systematic reviews (PROSPERO) site, registration number CRD42016041220 (8) and adheres to the Preferred Reporting Items for Systematic reviews and Meta-Analyses (PRISMA) guidelines (9).

\section{SEARCH STRATEGY}

A systematic search of the literature (without language restrictions) was performed. One reviewer searched for potentially eligible studies published from January 1, 2000 up to June 16, 2016 from the electronic databases PubMed and Scopus, using a comprehensive search strategy (Table 1), applying the principles of Boolean logic and medical subject headings (MeSH). All of the citations were imported into EndNote reference manager (Thompson Reuters version X7) and two reviewers (GM, SON) independently screened the titles and abstracts according to the inclusion/exclusion criteria (Table 2). Full texts of the studies were obtained and agreed on for eligibility. No disagreement regarding inclusion occurred. The search was supplemented by hand-searching the reference lists of included studies.

\section{ELIGIBILITY}

The inclusion and exclusion criteria used for this study with search limits and restrictions are as in Table 2.

\section{DATA EXTRACTION}

One reviewer (GM) extracted data from the included studies and a second reviewer (SON) checked the data for accuracy. Data extracted included author name and year and country/region of attack.

\section{QUALITY ASSESSMENT}

To the best of our knowledge, there is no tool validated to assess the quality of ecological studies (10). Nevertheless, the group exposure (terrorist attack) was assessed as 
Tab. 1: Search terms used to identify relevant studies.

\begin{tabular}{|l|l|}
\hline Exposure & Outcome \\
\hline Terror $^{\text {a }}$ & Birth gender ratio \\
\hline Bomb $^{\text {a }}$ & Human gender proportion at birth \\
\hline Shoot $^{\text {a }}$ & Human sex odds \\
\hline & Human sex ratio at birth \\
\hline & Male to female ratio at birth \\
\hline & Male:female birth ratio \\
\hline & Male:female ratio at birth \\
\hline & Male-female ratio \\
\hline & Male/female ratio \\
\hline & Secondary sex ratio \\
\hline & Secondary sex ratio at birth \\
\hline & Sex odds \\
\hline & Sex ratio \\
\hline & Sex ratio at birth \\
\hline
\end{tabular}

${ }^{a}$ Denotes wildcard to retrieve for example terror, terrorism, terrorist, terrorizing, etc. The AND operator was used between exposure and outcome while the OR operator was used within the exposure and outcome categories.

defined by the population that experienced the attack i.e. there was general consensus that the attack was terrorist in nature and the studies described them as such. Because the human live birth sex ratio of an entire population (and not a sample) was considered and the risk of misclassifying sex at birth is low (2), minimal bias was anticipated in measuring the outcome. The risk of bias in ascertaining the group exposure and group outcome were thus judged to be low.

\section{STATISTICAL ANALYSIS}

After identifying the final studies, it became clear it was possible to obtain the original data. By contacting the civil registration and vital statistics systems listed shortly, the reviewers acquired the anonymized primary data underlying the retrieved studies in order to facilitate a uniform analytic approach for the meta-analysis since the original studies used different statistical techniques and considered different analytic periods:

- United States Centers for Disease Control and Prevention, Vitalstats

- The National Institute of Statistics (Instituto Nacional de Estadística: INE)

- The English Office for National Statistics (Ms. Debbie Hague, Life Events \& Population Sources - personal communication)

- Statistics Norway Information Centre (Ms. Eva Hoel, Seksjon Befolkningsstatistikk, Statistisk Sentralbyrå personal communication)

Civil registration coverage of births was virtually $100 \%$ for the obtained live birth data. The methods for computing the human live birth sex ratio in exposed and non-exposed populations have been described in detail previously (11). These methods strive to minimize the inherent seasonality of the sex ratio at birth by considering the same period
Tab. 2: Inclusion and exclusion criteria.

\begin{tabular}{|l|l|l|}
\hline Participants & $\begin{array}{l}\text { Inclusion } \\
\text { Population exposed to } \\
\text { terrorist attack }\end{array}$ & Exclusion \\
\hline Exposure & Terrorist attack & No terrorist attack \\
\hline Comparison & $\begin{array}{l}\text { Control population } \\
\text { from immediate prior or } \\
\text { future years (same time } \\
\text { of the year) in same } \\
\text { geographic region not } \\
\text { exposed to terrorist } \\
\text { attack }\end{array}$ & No terrorist attack \\
\hline Outcome & $\begin{array}{l}\text { Human live birth sex } \\
\text { ratio reported at least } \\
\text { monthly }\end{array}$ & $\begin{array}{l}\text { Study without this } \\
\text { outcome }\end{array}$ \\
\hline Study design & Ecological & $\begin{array}{l}\text { Letters, editorials, } \\
\text { reviews, etc. }\end{array}$ \\
\hline Language & All languages & Not applicable \\
\hline Date & $\begin{array}{l}\text { Terrorist attack from } \\
\text { January 1 2000 to } \\
\text { present (June 16 2016) }\end{array}$ & $\begin{array}{l}\text { Terrorist attacks before } \\
\text { 2000 }\end{array}$ \\
\hline
\end{tabular}

${ }^{a}$ Direct observation of attack or indirectly via the media.

of the year and the confounding effect of, for example the climate and economy, by restricting analysis to two years before and after the attack(s). The month with the effect as reported in the primary studies (or the one with the lowest sex ratio - when there was no observed effect three to five months after an attack) was compared to the expected ratio for that time based on the observed sex ratio in the preceding and following two years. A p-value $<0.05$ was considered to be statistically significant.

Pooled odds ratios with $95 \%$ confidence intervals (CIs) were estimated for each study using Review Manager version 5.3.5 and the generic inverse variance method (12). Depending on the level of heterogeneity present, measured per the $\mathrm{I}^{2}$ statistic, the fixed or random-effects model was used. Where an $\mathrm{I}^{2}$ value of greater than $50 \%$ was obtained, this was considered moderate heterogeneity according to the Cochrane criteria (13) and the random-effects model was used. The meta-analysis was divided into a priori subgroups according to type of terrorist attack in line with the classification system used in the Global Terrorism Index (7): single person (lone wolf) attacks and multiple perpetrator attacks.

Post hoc sensitivity analysis was conducted since multiple studies included data from the same population. Three studies included data from the United States (US): One study included the population of New York (14), a second study included the population of California (15) and the third study included the entire US population (3). Therefore the following four sensitivity analyses were done (New York, California, California \& New York, and the entire US) to determine if the overall pooled OR would change. Research has shown that the $9 / 11$ attacks caused transient psychological distress in the whole of the US, but this distress was greatest in the New York City area (16). Informed by this fact, we chose New York for the final sensitivity analysis so as to capture the presumed maximum effect of the attacks. 


\section{RESULTS}

We retrieved 247 non-duplicated studies from the systematic search of the literature (Figure 2). Of these, 242 studies were excluded based on the title or abstract. Five studies covering five distinct terrorist attacks met the inclusion criteria $(3,14,15,17,18)$ and were included in the systematic review and meta-analysis (see Table 3 for study characteristics).

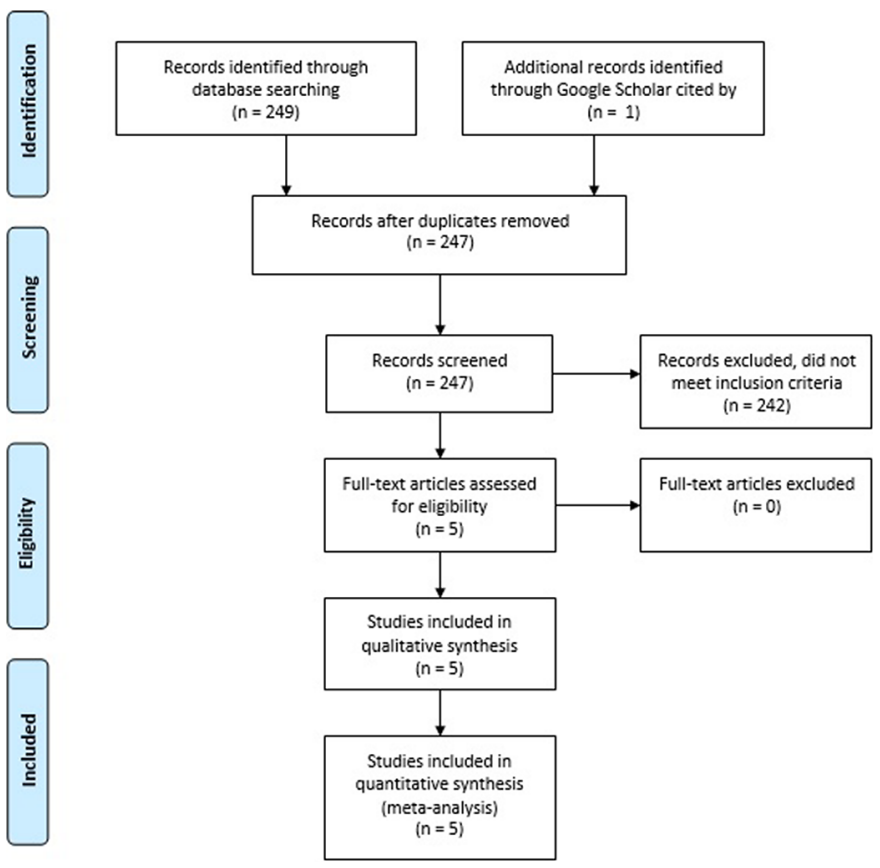

Fig. 2: Flow chart of studies identified for inclusion.

\section{META-ANALYSIS}

The overall pooled OR was statistically significant $0.9795 \%$ CI $(0.94-1.00)(p=0.03)\left(I^{2}=63 \%\right)$, with a three percent decline in the odds of having a male live birth in populations exposed to terrorist attack(s) compared to referent un-exposed populations (Figure 3). This significant result did not change for three of the four sensitivity analyses (New York, California, California \& New York), but the results did alter when the entire US population was used $(\mathrm{p}=0.06)$.

\section{DISCUSSION}

\section{PRINCIPAL FINDINGS}

The striking finding was that more deaths from pregnancy loss than direct casualties were estimated for Norway and Connecticut following the 2011 Norway attacks and 2012 Sandy Hook Elementary School shooting. Indeed, Norway appeared to experience a "triple hit" from direct deaths, excess pregnancy losses and an increase in the suicide rate (19), all of which were linked to the attack. To the best of our knowledge this is the first time the "triple hit" signature of deaths following a terrorist attack has been described in the literature. Other attacks might not show this signature, depending on contextual factors, such as the 9/11 attacks wherein the suicide rate remained stable in the United States and even dipped significantly in the immediate vicinity of the New York attacks (20).

The other striking finding is that terrorist attacks by single perpetrators had a larger effect size than those by multiple perpetrators. One possible explanation in the context of this study was that an attack by an 'insider' rather than an 'outsider' was perhaps more shocking/ stressful to the community, as was possibly the case for the Norway and Sandy Hook Elementary School attacks. Such individuals are trusted, and violent attacks from such individuals are therefore unanticipated and doubly appalling.

\section{STRENGTHS AND LIMITATIONS}

Being able to obtain the raw live birth data from modern civil registration and vital statistics systems that are highly complete, accurate and timely was a major strength.

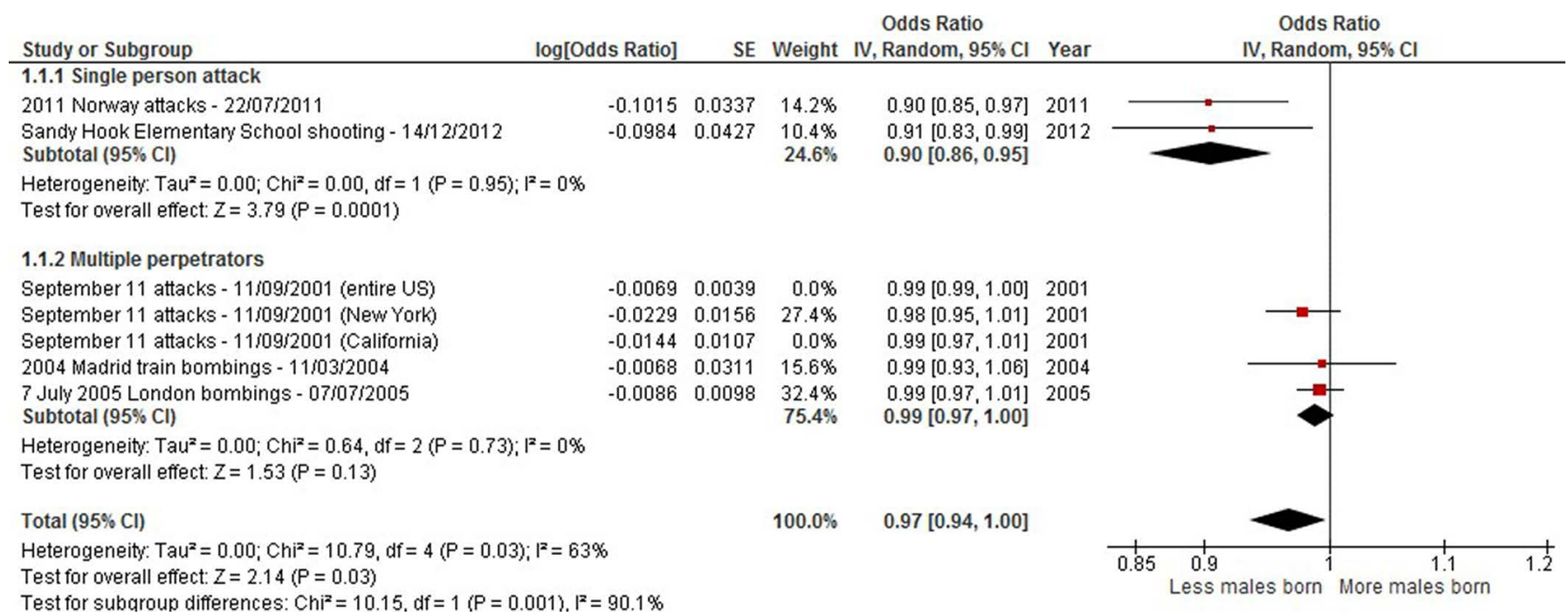

Fig. 3: Forest plot of random effects meta-analysis of the association between early 21st century terrorist attacks and the human live birth sex ratio. Please note the striking difference in effect size between single person attacks and attacks by multiple perpetrators. The September 11 attacks for California and the entire United States (US) are shown so as to display their odds ratio point estimates and 95\% confidence intervals, but these did not contribute (Weight $=0.0 \%$ ) to the pooled estimate. 
Tab. 3: Characteristics of included terrorist attacks with calculated estimates of males lost.

\begin{tabular}{|c|c|c|c|c|c|c|c|}
\hline Attack & $\begin{array}{l}\text { Summary of } \\
\text { attack }\end{array}$ & $\begin{array}{l}\text { Month of dip } \\
\text { and number } \\
\text { of months } \\
\text { after attack }\end{array}$ & Population & $\begin{array}{l}\text { Percent } \\
\text { males in } \\
\text { control } \\
\text { population }\end{array}$ & $\begin{array}{l}\text { Percent } \\
\text { males after } \\
\text { attack }\end{array}$ & $\begin{array}{l}\text { Number } \\
\text { of males } \\
\text { lost (point } \\
\text { estimate) }\end{array}$ & $\begin{array}{l}\text { 95\% confidence } \\
\text { interval }^{\mathrm{a}}\end{array}$ \\
\hline \multicolumn{8}{|l|}{ Single person attack } \\
\hline $\begin{array}{l}2011 \text { Norway } \\
\text { attacks - 22/07/2011 } \\
{[17](\text { Grech, 2015) }}\end{array}$ & $\begin{array}{l}77 \text { lives lost in } \\
\text { two attacks } \\
\text { a few hours apart } \\
\text { by a sole male } \\
\text { perpetrator (car } \\
\text { bomb and mass } \\
\text { shooting) }\end{array}$ & $\begin{array}{l}\text { December } \\
2011 \\
\text { ( 5 months) }\end{array}$ & Norway & $51.4 \%$ & $48.9 \%$ & 230 & 392 lost - 78 lost \\
\hline $\begin{array}{l}\text { Sandy Hook } \\
\text { Elementary } \\
\text { School shooting - } \\
\text { 14/12/2012 b [17] } \\
\text { (Grech V, 2015) }\end{array}$ & $\begin{array}{l}28 \text { lives lost in an } \\
\text { attack by a sole } \\
\text { male perpetrator } \\
\text { (school shooting) }\end{array}$ & $\begin{array}{l}\text { April } 2013 \\
\text { ( 4 months) }\end{array}$ & Connecticut & $51.3 \%$ & $48.8 \%$ & 147 & 284 lost -21 lost \\
\hline \multicolumn{8}{|l|}{ Multiple perpetrators } \\
\hline $\begin{array}{l}\text { September } 11 \\
\text { attacks - 11/09/2001 } \\
\text { (entire US) [3] } \\
\text { (Bruckner et al., 2010) }\end{array}$ & $\begin{array}{l}2996 \text { lives lost in } \\
\text { multiple attacks } \\
\text { by multiple } \\
\text { perpetrators } \\
\text { (aircraft flying } \\
\text { into inhabited } \\
\text { buildings) }\end{array}$ & $\begin{array}{l}\text { December } \\
2001 \\
\text { ( 3 months) }\end{array}$ & $\begin{array}{l}\text { United } \\
\text { States of } \\
\text { America }\end{array}$ & $51.1 \%$ & $51.0 \%$ & 1156 & 2449 lost - 166 gained \\
\hline $\begin{array}{l}\text { September } 11 \\
\text { attacks - 11/09/2001 } \\
\text { (New York) [14] } \\
\text { (Catalano et al., 2006) }\end{array}$ & As above & $\begin{array}{l}\text { January } 2002 \\
\text { ( 4 months) }\end{array}$ & $\begin{array}{l}\text { New York } \\
\text { State }\end{array}$ & $51.1 \%$ & $50.5 \%$ & 240 & 569 lost - 93 gained \\
\hline $\begin{array}{l}\text { September } 11 \\
\text { attacks - 11/09/2001 } \\
\text { (California) [15] } \\
\text { (Catalano et al., 2005) }\end{array}$ & As above & $\begin{array}{l}\text { December } \\
2001 \\
\text { ( 3 months) }\end{array}$ & California & $51.9 \%$ & $51.2 \%$ & 318 & 789 lost - 153 gained \\
\hline $\begin{array}{l}2004 \text { Madrid } \\
\text { train bombings - } \\
11 / 03 / 2004^{b}[18] \\
\text { (Grech and Mamo, } \\
2016 \text { ) }\end{array}$ & $\begin{array}{l}191 \text { lives lost in } \\
\text { multiple attacks } \\
\text { by multiple } \\
\text { perpetrators } \\
\text { (bombing } \\
\text { commuter trains) }\end{array}$ & $\begin{array}{l}\text { August } 2004 \\
\text { ( 5 months) }\end{array}$ & $\begin{array}{l}\text { Madrid } \\
\text { province }\end{array}$ & $51.5 \%$ & $51.3 \%$ & 19 & 196 lost - 148 gained \\
\hline $\begin{array}{l}7 \text { July } 2005 \text { London } \\
\text { bombings - } \\
\text { 07/07/2005 [18] } \\
\text { (Grech and Mamo, } \\
\text { 2016) }\end{array}$ & $\begin{array}{l}56 \text { lives lost in } \\
\text { multiple attacks } \\
\text { by multiple } \\
\text { perpetrators } \\
\text { (bombing } \\
\text { commuter trains } \\
\text { and a bus) }\end{array}$ & $\begin{array}{l}\text { November } \\
2005 \\
\text { ( 4 months) }\end{array}$ & $\begin{array}{l}\text { England } \\
\text { and Wales }\end{array}$ & $51.3 \%$ & $51.1 \%$ & 232 & 752 lost - 291 gained \\
\hline
\end{tabular}

Please note for Norway there were almost three times $(230 \div 77)$ more pregnancy losses compared to direct casualties. For Connecticut, there was an approximately five times $(147 \div 28)$ greater toll. US - United States of America, ${ }^{a}$ Rounded to the nearest whole number, ${ }^{b} 2002$ and 2015 missing from referent population.

This also allowed uniform statistical analysis, ensuring comparability between the different terrorist events. Needless to mention, the transparent, systematic and reproducible methodology with no language restriction to the search is another major notable strength. Searching only two biomedical databases, PubMed and Scopus (the largest database of peer-reviewed literature), and not considering gray literature limited our study as we may have missed relevant studies. Since five terrorist attacks were identified with two heterogeneous subgroups, it was not possible to adequately assess publication bias, which, as previously discussed (5), might affect the sex ratio at birth field. The attacks considered herein account for over $90 \%$ of deaths from terrorism in the West, but less than $3 \%$ of global terror deaths in the 15 years from 2000 to 2014 inclusive (7). Thus another limitation is that this study's findings might not be reproducible beyond a Western world setting to other places that have experienced terrorist attacks, for example in Africa and Asia which also happen to have limited civil registration and vital statistics systems, precluding detailed analysis. The limitations of ecological studies (21), like the limited ability to infer to the individual level (ecological fallacy) apply to this study. Nevertheless the ecological study is arguably the best to evaluate the impact of a population stressor on a population outcome (22).

The purpose of terrorism is the calculated infliction of population stress since terrorist acts endeavor to shock 
populations and thus draw media attention for perceived political purposes. For this reason, terrorists strive to influence a much wider audience than the individuals that are targeted, often with success (23). Society struggles to come to terms with the motivation(s) behind these events, a phenomenon known as "attribution theory," the need to assign motivation so as to understand events, "how else to explain the inexplicable" (24).

Unlike the original studies on $9 / 11(3,14,15)$ our analytical method did not find a statistically significant association between the attack and the human live birth sex ratio in New York, California and the entire United States. A statistically insignificant result does not automatically mean a lack of effect (25). One reason for this difference is that our analysis included live birth data up to 2004 , while the primary studies used data up to 2002. In addition, we used restriction - an epidemiologic technique - to take confounding into account and a different strategy was used to account for autocorrelation. However, we observed the same striking patterns. For example, the California December 2001 (three months after the attack) sex ratio was the lowest ever observed monthly sex ratio from 1994 to 2004 inclusive for that population, as well as total births, suggesting an obvious influence of the attacks on the sex ratio at birth. Therefore, although we used different statistical techniques, our findings are in agreement with the primary studies. Furthermore, a recent study (16) revealed that population level psychological distress following the 9/11 attacks lasted for about one month and then resolved. A similar pattern was observed with the sex ratio at birth after $9 / 11$ albeit with the expected lag, from the time of miscarriage/stillbirth to when live birth would have occurred. This temporally related transient one month dip in both psychological distress and the sex ratio at birth in the same population further cements the causal relationship between stress engendered by terrorist attacks and a subsequent decline in the live birth sex ratio.

One would anticipate that an effect for the 2005 London bombings would be observed in that city in a similar way to New York for 9/11. Unfortunately live birth data was only available for England and Wales combined, thereby presumably attenuating the observed effect as we saw for the entire US in this study. Additionally, Londoners were forewarned with regard to possible attacks. For example, in August 2004, leaflets were mailed to all households with advice as to what to do in the event of a terrorist attack (26). Thus, the lack of effect seen for the London bombings could in part be attributed to this public health intervention of priming the population, thereby dampening the stress engendered by the attacks.

In addition, the lack of effect on the live birth sex ratio following the 2005 London bombings is consistent with a population-based study conducted in the North West of England that failed to demonstrate a change in the stillbirth rate in women exposed to the attacks while pregnant or six months before they conceived (27). However, the study showed a small but significant $16 \mathrm{~g}$ reduction in birth weight in these North West England women 'exposed' to the London attacks via the media, compared to a referent unexposed group, suggesting that the terrorist attacks in central London did have a measurable obstetric impact, which was nonetheless not severe enough to perturb the number of stillbirths, which are on the causal pathway to subsequent alteration of the sex ratio at birth.

Our pooled findings suggest that stress may have precipitated spontaneous abortions in already pregnant women who were negatively influenced by the diverse stressful events studied in this paper, in accordance with the Trivers-Willard hypothesis (28). Weaker fetuses are typically affected, resulting in a greater loss of male than female fetuses (3). This is confirmed by the fact that surviving male births after $9 / 11$ produced males that apparently had better than expected cognitive development (29).

While these are relatively transient male fetal losses, public health authorities should utilise the live birth sex ratio which is cheap, quick and easy to measure in order to quantify the effects of stress from significant events on entire populations, and therefore refine and implement interventions to mitigate future losses.

It is not surprising that attention has not been drawn prominently to pregnancy loss that can by far outstrip the direct deaths from terrorist attacks. Indeed, stillbirth has been termed the neglected epidemic (30). This subject deserves serious public health consideration and action.

As mentioned in the introduction, calamitous events have also been associated with a subsequent decline in the sex ratio at birth (4). Future systematic reviews and meta-analyses considering such events are warranted.

\section{CONCLUSIONS}

Terrorist attacks in the early 21st century were statistically significantly associated with a small three percent reduction in the odds of having a live male birth three to five months afterwards because of excess male pregnancy loss. This effect was particularly strong for attacks perpetrated by single, 'lone wolf' individuals, so much so that estimates of males lost during pregnancy because of maternal stress engendered by these attacks through miscarriage or stillbirth were about three $(230 \div 77)$ and five times $(147 \div$ 28 ) greater than direct deaths from the 2011 Norway attacks and 2012 Sandy Hook Elementary School shooting respectively. Because pregnancy loss remains an important public health challenge this subject deserves serious public health consideration and action.

\section{FUNDING}

GM is supported by the Irish Centre for Fetal and Neonatal Translational Research (INFANT) (grant no. 12/RC/2272). The other authors report no support relevant to this article.

\section{COMPETING INTERESTS}

None declared.

\section{ACKNOWLEDGEMENTS}

GM acknowledges Ermelinda Furtado Da Luz and Barrie Tyner of the Department of Epidemiology and Public 


\section{Health, University College Cork for helpful discussions on the topic.}

\section{REFERENCES}

1. Graunt J. Natural and political observations mentioned in a following index, and made upon the Bills of Mortality. London, England: Printed by T. Rycroft for John Martin, J. Allestry, and T. Dicas, 1662. Reprinted by Wilcox WF, ed. Baltimore, MD: Johns Hopkins University Press, 1939.

2. Davis DL, Gottlieb MB, Stampnitzky JR. Reduced ratio of male to female births in several industrial countries: a sentinel health indicator? JAMA 1998; 279: 1018-1023.

3. Bruckner TA, Catalano R, Ahern J. Male fetal loss in the U.S. following the terrorist attacks of September 11, 2001. BMC Public Health 2010; 10: 273.

4. Catalano R, Yorifuji T, Kawachi I. Natural selection in utero: evidence from the Great East Japan Earthquake. Am J Hum Biol 2013; 25: 555-559.

5. Bonde JP, Wilcox A. Ratio of boys to girls at birth. BMJ 2007; 334: 486-487.

6. Almogy G, Rivkind AI. Terror in the 21st century: milestones and prospects - part I. Curr Probl Surg 2007; 44: 496-554.

7. Institute for Economics and Peace. Global Terrorism Index 2015. Available: http://economicsandpeace.org/wp-content /uploads/2015/11/Global-Terrorism-Index-2015.pdf, 2015 (accessed 25.09.16).

8. Masukume G, O'Neill S, Khashan A, Kenny L, Grech V. The association between terrorist attacks and the human live birth sex ratio during the early 21 st century: a systematic review and meta-analysis. PROSPERO CRD42016041220. Available: http://www.crd.york .ac.uk/PROSPERO/display_record.asp?ID=CRD42016041220, 2016 (accessed 25.08.16).

9. Moher D, Liberati A, Tetzlaff J, Altman DG; PRISMA Group. Preferred reporting items for systematic reviews and meta-analyses: the PRISMA statement. Ann Intern Med 2009; 151: 264-269.

10. Betran AP, Torloni MR, Zhang J, What is the optimal rate of caesarean section at population level? A systematic review of ecologic studies. Reprod Health 2015; 12: 57.

11. Masukume G, Grech V. The sex ratio at birth in South Africa increased 9 months after the 2010 FIFA World Cup. Early Hum Dev 2015; 91 : 807-809.

12. Deeks JJ, Higgins JP. Statistical algorithms in Review Manager 5. Statistical Methods Group of The Cochrane Collaboration. Available: http:// tech.cochrane.org/revman/documentation/statistical-methods -in-revman-5.pdf, 2010 (accessed 27.06.16).
13. Higgins JP, Thompson SG. Quantifying heterogeneity in a meta-analysis. Stat Med 2002; 21: 1539-1558.

14. Catalano R, Bruckner T, Marks AR, Eskenazi B. Exogenous shocks to the human sex ratio: the case of September 11, 2001 in New York City. Hum Reprod 2006; 21: 3127-3131.

15. Catalano R, Bruckner T, Gould J, Eskenazi B, Anderson E. Sex ratios in California following the terrorist attacks of September 11, 2001. Hum Reprod 2005; 20: 1221-1227.

16. Tsai AC, Venkataramani AS. Communal bereavement and resilience in the aftermath of a terrorist event: Evidence from a natural experiment. Soc Sci Med 2015; 146: 155-163.

17. Grech V. Terrorist attacks and the male-to-female ratio at birth: The Troubles in Northern Ireland, the Rodney King riots, and the Breivik and Sandy Hook shootings. Early Hum Dev 2015; 91: 837-840.

18. Grech V, Mamo J. Terrorist attacks and the male to female ratio at birth: The bombings of Madrid (3/2004) and London (7/2005). Malta Med J 2016; 28: 52-55.

19. Strand LB, Mukamal KJ, Halasz J, Vatten LJ, Janszky I. Short-Term Public Health Impact of the July 22, 2011, Terrorist Attacks in Norway: A Nationwide Register-Based Study. Psychosom Med 2016; 78: 525-531.

20. Claassen CA, Carmody T, Stewart SM, et al. Effect of the 11 September 2001 terrorist attacks in the USA on suicide in areas surrounding the crash sites. Br J Psychiatry 2010; 196: 359-364.

21. Hart J. On ecological studies: a short communication. Dose Response 2011; 9: 497-501.

22. Pearce N. Epidemiology in a changing world: variation, causation and ubiquitous risk factors. Int J Epidemiol 2011; 40: 503-512.

23. DiMaggio C, Galea S. The behavioral consequences of terrorism: a meta-analysis. Acad Emerg Med 2006; 13: 559-566.

24. Corrigan PW. Understanding Breivik and Sandy Hook: Sin and sickness? World Psychiatry 2013; 12: 174-175.

25. Rothman KJ. Six persistent research misconceptions. J Gen Intern Med 2014; 29: 1060-1064.

26. Rubin GJ, Brewin CR, Greenberg N, Simpson J, Wessely S. Psychological and behavioural reactions to the bombings in London on 7 July 2005: cross sectional survey of a representative sample of Londoners. BMJ 2005; 331: 606.

27. Nugent JL, Khashan AS, Baker PN. Reduced infant birth weight in the North West of England consequent upon 'maternal exposure' to 7/7 terrorist attacks on central London. J Obstet Gynaecol. 2011; 31: 118-121.

28. Trivers RL, Willard DE. Natural selection of parental ability to vary the sex ratio of offspring. Science 1973; 179: 90-92.

29. Bruckner TA, Nobles J. Intrauterine stress and male cohort quality: the case of September 11. Soc Sci Med 2013; 76: 107-114.

30. Horton R, Samarasekera U. Stillbirths: ending an epidemic of grief. Lancet 2016; 387: 515-516. 